\title{
Protection systems against debris flows
}

\author{
R. Luis Fonseca ${ }^{1}$, C. Raïmat Quintana ${ }^{1}$, L. Laguna Megal ${ }^{1}$ \\ \& A. Roth ${ }^{2}$ \\ ${ }^{1}$ Geobrugg Ibérica, S.A. Spain \\ ${ }^{2}$ Geobrugg Fatzer AG, Switzerland
}

\begin{abstract}
Debris flows are natural hazards which look like a combination of flood, land and rock slide. The phenomenon is also called mud or debris avalanche due to its similar flow behavior compared with snow avalanches. Debris flows regularly cause severe damages in mountainous areas like such as the Alps (Brig 1993, Sachseln 1997, Gondo 2000). Like rock fall, the debris flows loads act mainly dynamically on a protection barrier. But in contrast to falling rocks debris flows are not punctual impacts but a distributed load on the protection system. A further difference between the two hazards is the fact that rockfalls are single events while debris flows mostly occur in surges. Experiences from North America, Japan and Europe prove that flexible protection systems like the Geobrugg VX/UX Systems have an ideal bearing behavior to stop dynamic loads such as debris flows due to their large deformation capacity

Keywords: debris flow, ring net, ROCCO, dynamic barrier, muds.
\end{abstract}

\section{Introduction}

After the successful result of the introduction of the Geobrugg ROCCO ${ }^{\circledR}$ ring net several years ago, in the Rockfall Protection Systems, and as a result of the necessity of the avalanche control of materials dragged by the action of the water (rocks, mud, trees, etc.). Geobrugg was studying the possibilities of placing properly braced, this type of ring net within the natural channel of these flows, obtaining with it to stop the heavy and dangerous blocks and trees and being let pass the water.

In February 1995 a debris flow of $60 \mathrm{~m}^{3}$ was held back by a rockfall barrier of BRUGG Cable Products Inc. (BCPI) along California State Road 41 (County of San Luis Obispo). The result was that the road was not affected by the natural 
hazard. As a result of this event detailed studies were carried out in the year 1.996 by the United States Geological Survey (USGS), the California Polytechnic State University (CALPOLY) and the California Department of Transportation (CALTRANS). On the test flume of H.J. Andrews Experimental Forest, Blue River, Oregon the debris flow load on different protection barriers under different conditions was analyzed. The concrete channel has a total length of $95 \mathrm{~m}$, a width of $2 \mathrm{~m}$ and the lateral walls are $1,2 \mathrm{~m}$ high. The top $88 \mathrm{~m}$ have an inclination of $31^{\circ}$ and the lower $7 \mathrm{~m}$ one of $3^{\circ}$. The test program contained 6 tests with debris volumes of approx. $10 \mathrm{~m}^{3}$ and impact velocities between 5 and $9 \mathrm{~m} / \mathrm{s}$. The composition of the test debris was $24 \%$ gravel, $74 \%$ sand, $2 \%$ silt and clay. The tests showed that ring nets with laid-on chain-link mesh achieve the best retention performance. Only $0,05 \%$ of the test material passed the barrier. This is mainly important if there is a road which has to be protected and has to be drivable all the time. The brake elements engaged, only border rings were deformed plastically and the ropes and posts were not damaged.

In 1998 the RX-150 system (1.500kJ) installed in Aobandani, Japan stopped a debris flow with a volume of $750 \mathrm{~m}^{3}$. The maximum deflection of the system was between 2 and $3 \mathrm{~m}$ and the remaining system height was about $3,5 \mathrm{~m}$ (original height $5 \mathrm{~m}$ ). After cleaning of the barrier only the brake elements had to be replaced while the ropes and the ring net were not damaged.

In March 2000 a $200 \mathrm{~m}^{3}$ debris flow hit a RX-075 barrier $(750 \mathrm{~kJ})$ in Seewalchen, Austria. There were also rooted out logs in the debris flow material, $2 \mathrm{~m}$ of the original height of $3 \mathrm{~m}$, remained after the impact and the deflection of the system was about $2 \mathrm{~m}$. The brake elements engaged properly and were replaced after the cleaning of the system. No further repairs were necessary.

In November of 2001 in Fikushima, Japan, happened a snow sliding of a volume of $400 \mathrm{~m}^{3}$, stopped by a barrier RX-075. In 2002 in Japan the Tabata's project was made, which has stopped events that have been recorded of more of $3.000 \mathrm{~m}^{3}$ of blocks and muds. The design of big concrete blocks for anchorage is not allowed in many countries because of environmental reasons.

After storms of the winter of 2.002 in Santa Cruz de Tenerife in the Canary Islands, Geobrugg designed and installed a solution of debris control by means of two lines of barriers, with capacity of $850 \mathrm{~m}^{3}$.

In 2.004 Geobrugg installed in the port Gaviota the South of California, Highway 101, barriers for debris flow control. In June happened an event that dragged a volume $300 \mathrm{~m}^{3}$, it was contained successfully by the installation.

\section{Design principles}

\subsection{Principles}

The Geobrugg VX/ UX Protection System against Debris Flow is based on the approved and from independent institute certified RX Protection System against Rockfall. Due to the aerial load of debris flows some adaptations are necessary: stronger support ropes, brake elements with higher capacities and weaker $R O C C O^{\circledR}$ ring net due to the distributed load; stronger anchorage; protection of the top support ropes against abrasion. 
Mode of action: Due to the permeable construction of a Geobrugg VX/ UX ring net barrier an impacting granular debris flow is drained as a result of the retention of rougher material and the passing of water and fine parts. Through this dewatering a certain length of the debris flow is stopped (the so called relevant length / mass) which stops afterwards the rest of the flow.

The energy of a debris flow is mainly absorbed by the brake elements. The task of the ring net is to carry the load to the support ropes. The Rocco ring net has a proven capacity to absorb punctual impacts and has therefore ideal features for debris flow impacts because most of the large blocks in a granular debris flow are transported at the front of the flow. Experiences show further that the links between Rocco rings are much stronger than the clips of wire rope nets.

Abrasion protection: The abrasion protection has to be investigated accurately, if the barrier is intended to remain filled with debris.

Barrier location: For the location of a barrier a torrent section as straight as possible should be chosen. The inclination should be as small as possible to reduce the impact velocity and to enlarge the retention capacity. The location should further be well accessible to ensure an immediate inspection and a cleaning of the barrier if necessary. The bed at the barrier location has to be stable enough to withstand the occurring loads; otherwise additional protective measures have to be carried out.

Maintenance: The barriers should be checked regularly and cleaned and repaired if necessary immediately after an event. Experiences show that the cleaning of a barrier is easily practicable. Engaged brake elements have to be replaced. This is the only repair effort to be done even after big events. If the barrier is intended to remain filled with debris, static loads and corrosion have to be considered.

Range of application: The range of application of the VX/ UX Protection System against Debris Flow is limited by a maximum volume of about $1.000 \mathrm{~m}^{3}$ and a maximum flow velocity of about 5 to $6 \mathrm{~m} / \mathrm{s}$.

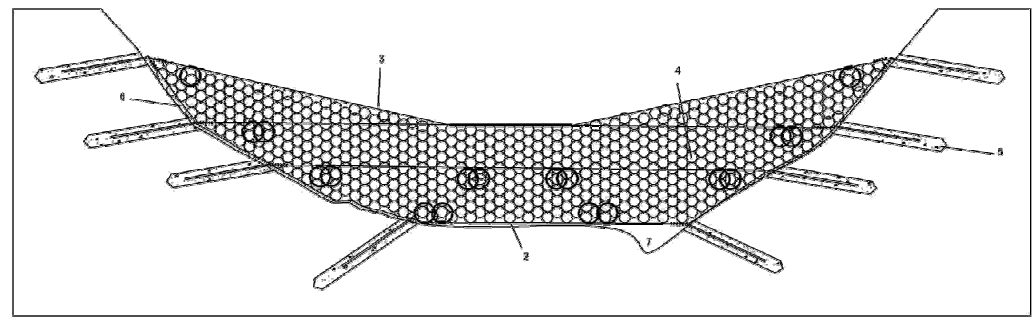

Figure 1: Geobrugg VX barrier.

\subsection{Design height}

The maximum retention capacity of the barrier is dependent on the topographic situation and the height of the system. Experiences indicate that the gradient of the deposit behind the barrier corresponds to $2 / 3$ of the original gradient of the torrent. 


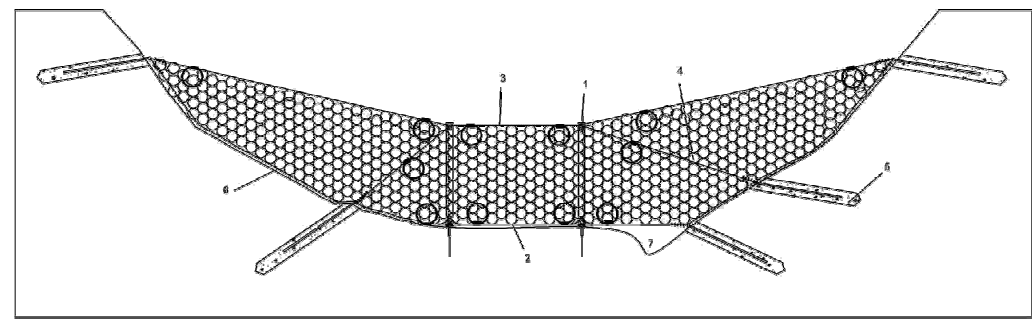

1.- steel post

2.- bottom support rope
3.- top support rope

4.- middle support rope
5.- flexible anchor

6.- lateral support rope

7.- over flow

Figure 2: Geobrugg UX barrier.

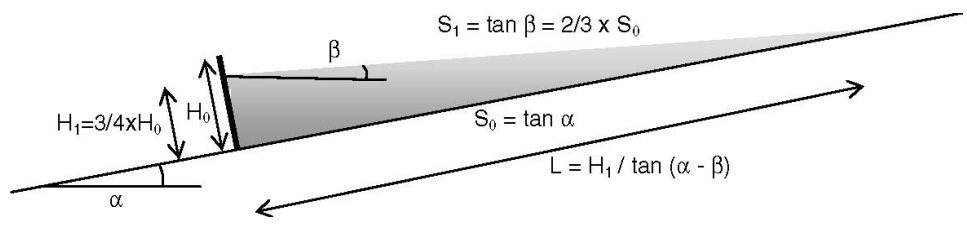

Figure 3: Deposit behind the barrier (direction profile).

The remaining barrier height is about $3 / 4$ of the original height. Thus the minimum barrier height is determined as follows:

$$
\mathrm{H}_{\mathrm{o}}=\sqrt{\frac{32}{9} \cdot \frac{\mathrm{V}_{\mathrm{DF}}}{\mathrm{b}} \cdot \tan \left[\arctan \left(\mathrm{S}_{\mathrm{o}}\right)-\arctan \left(\frac{2}{3} \cdot \mathrm{S}_{\mathrm{o}}\right)\right]}
$$

If the design height gets to high, a flatter and/or wider barrier location has to be chosen.

\section{Dimensioning parameters}

\subsection{General characterization}

Natural phenomena which are located between landslide/ rockfall and bed load transportation in water flows are called debris flows. They mostly occur as a result of heavy rainfall but can also be triggered by other events such as melting snow or dam failure. The pre-conditions for the appearance of debris flows are mainly steep slopes, enough material which is easy to mobilize and enough water to trigger the flow.

Under a mechanical point of view debris flows can be divided in two main types:

Mud flows, which mainly consist of water and fine material, which is more or less uniformly distributed. 
Granular debris flows, which consist of water, fine and rougher material. The larger components are mostly accumulated at the front of the flow and play an important role in the overall flow behavior of a granular debris flow.

Observations of debris flows show that they mostly occur in surges. The observations show further that the velocity and the consistency of the surges may vary from surge to surge. Therefore it is important to use load parameters always with a sufficient variation.

\subsection{Parameters}

Although debris flow load parameters are crucial input data to dimension protection systems, only few research projects were carried out on this subject so far. This is a result of the still limited understanding of the mechanics of debris flows. It is further hard to measure debris flow parameters adequately during real events. Several mechanical and rheological models were proposed to analyze and predict debris flows. Due to the lack of field data for comparison, Rickenmann suggests to use empirical relationships. These empirical relationships are applied in the following design concept. In the direction profile the flow depth $\mathrm{h}$, the cross section A and the front flow velocity $\mathrm{v}$ of the debris flow can be defined:

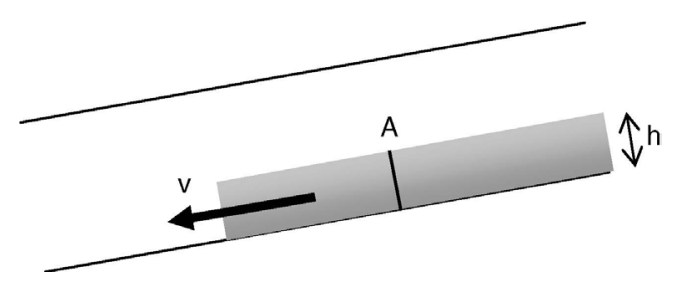

Figure 4: Direction profile of a debris flow.

At the location of the barrier the stopped debris flow has to be modelled in the cross section. In most of the cases there are inclined banks and the experiences show that the maximum depth of the accumulated material is in the middle of the torrent. For simplifying it is assumed that the width of the flow corresponds to the average bed width. The idealised cross section of the stopped flow should have more or less the same area than the expected flow face.

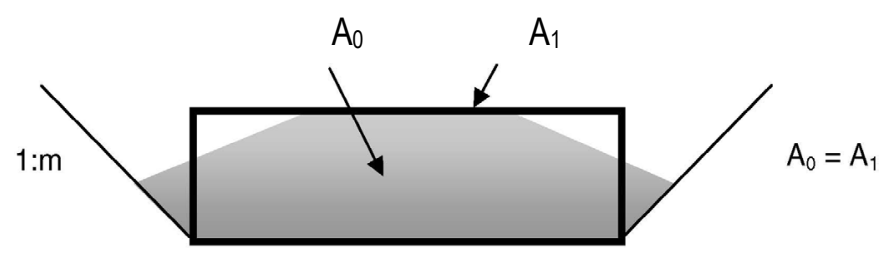

b

Figure 5: Cross section of a stopped debris flow. 
The first step is to estimate a possible debris flow volume $V_{\mathrm{DF}}$. A lot of different formulas are proposed in the literature, but they are all not very reliable. Therefore observations and experiences at the location of the project should be used. A further method is to execute a geomorphologic assessment of the sediment potential. The volume for flexible protection system lays in a range of $100 \mathrm{~m}^{3}$ to $1.000 \mathrm{~m}^{3}$.

Several studies proved that the peak discharge of a debris flow is correlated to its volume. There are different relations for granular debris flows and mud flows. Mizuyama et al. propose for a granular debris flow (debris avalanche) the following empirical relationship between peak discharge and debris flow volume:

$$
\mathrm{Q}_{\mathrm{P}}=0,135 \mathrm{~V}_{\mathrm{DF}}^{0,78}
$$

Equation following represents the according relationship for mud flows:

$$
\mathrm{Q}_{\mathrm{P}}=0,0188 \mathrm{~V}_{\mathrm{DF}}^{0,79}
$$

By using the peak discharge it is possible to estimate the average flow velocity $\mathrm{V}$ at the front of the flow. Rickenmann proposes a regime condition for the relation between velocity, peak discharge and slope inclination (friction considered). $\mathrm{S}$ refers to the gradient of the torrent (tangent of the slope inclination in degrees). Typical values are $\mathrm{S}=0,18\left(10^{\circ}\right), \mathrm{S}=0,36\left(20^{\circ}\right)$ or $\mathrm{S}=0,58\left(30^{\circ}\right)$.

$$
\mathrm{v}=2,1 \mathrm{Q}_{\mathrm{P}}^{0,33} \mathrm{~S}^{0,33}
$$

Japanese guidelines suggest a Manning-Strickler equation to determine the average flow velocity $\mathrm{n}_{\mathrm{d}}$ refers to a pseudo-manning value which is typically between $0,05 \mathrm{~s} / \mathrm{m}^{1 / 3}$ and $0,18 \mathrm{~s} / \mathrm{m}^{1 / 3}$, while the values for granular debris flows lay between $0,10 \mathrm{~s} / \mathrm{m}^{1 / 3}$ y $0,18 \mathrm{~s} / \mathrm{m}^{1 / 3}$.

$$
\mathrm{v}=1 / \mathrm{n}_{\mathrm{d}} \mathrm{H}^{0,67} \mathrm{~S}^{0,5}
$$

The flow depth $\mathrm{h}$ is calculated by using the cross section and the peak discharge.

$$
\mathrm{h}=\mathrm{Q}_{\mathrm{p}} / \mathrm{v} \mathrm{b}
$$

It is recommended to use both equations and compare the results.

The density of the material is based on empirical values and is about:

$$
\gamma_{\mathrm{DF}}=18-23 \mathrm{kN} / \mathrm{m}^{3}
$$

\subsection{Total debris flow energy.}

As a result of the dewatering of the debris flow during the impact on a permeable barrier not the whole mass of the flow has to be stopped but only a relevant length or mass. The relevant mass $M$ is determined as follows: It is assumed that only this part of the flow is acting dynamically which fills up the barrier with debris between the time of contact and the time of the maximum deflection of the barrier. In the Oregon tests with volumes of $10 \mathrm{~m}^{3} \mathrm{~T}_{\mathrm{imp}}$ was about $1 \mathrm{~s}$. Real debris flows are expected to be much larger and therefore the braking time will also last longer. $\mathrm{T}_{\mathrm{imp}}$ is estimated to be between $1 \mathrm{~s}$ and $4 \mathrm{~s}$.

$$
\mathrm{T}_{\mathrm{imp}}=1 \mathrm{~s}-4 \mathrm{~s} \quad \text { (depending on velocity and barrier length) }
$$


The relevant mass is consequently calculated as follows:

$$
\mathrm{M}_{\mathrm{DF}}=\gamma_{\mathrm{DF}} \mathrm{Q}_{\mathrm{DF}} \mathrm{t}
$$

The total energy is determined by using the law of the kinetic energy.

$$
\mathrm{E}_{\mathrm{K}}=0,5 \mathrm{M}_{\mathrm{DF}} \mathrm{v}^{2}
$$

Thus the total kinetic energy is between $100 \mathrm{~kJ}$ and $3.000 \mathrm{~kJ}$.

The dimensioning energy may not be compared with design energies of RX rockfall protection systems. The reasons for that are given in the following table.

Table 1

\begin{tabular}{|l|l|l|l|}
\hline & Rockfall & Debris Flow & $\begin{array}{l}\text { Influence of a debris } \\
\text { flow on a flexible barrier } \\
\text { compared to a rockfall }\end{array}$ \\
\hline Load & $\begin{array}{l}\text { Punctual } \\
(1 \text { section })\end{array}$ & $\begin{array}{l}\text { distributed } \\
\text { (several sections })\end{array}$ & $\begin{array}{l}\text { positive due to smaller } \\
\text { local loads }\end{array}$ \\
\hline $\begin{array}{l}\text { Impact } \\
\text { time }\end{array}$ & $0,2-0,5 \mathrm{~s}$ & $1-4 \mathrm{~s}$ & $\begin{array}{l}\text { positive due to smoother } \\
\text { deceleration }\end{array}$ \\
\hline $\begin{array}{l}\text { Type of } \\
\text { impact }\end{array}$ & single impact & in surges & $\begin{array}{l}\text { negative due to static } \\
\text { loads in the system after } \\
\text { the first impact }\end{array}$ \\
\hline $\begin{array}{l}\text { Braking } \\
\text { distance }\end{array}$ & $5-8 \mathrm{~m}$ & $2-3 \mathrm{~m}$ & $\begin{array}{l}\text { negative due to higher } \\
\text { dynamic forces }\end{array}$ \\
\hline
\end{tabular}

\subsection{Computer modelling}

Within the scope of a KTI project (Commission for Technology and Innovation) a computer program was developed to simulate the impact of rocks into flexible ring net barriers. The project was executed with collaboration of the ETH Zurich (Federal Institute of technology) and the WSL Birmensdorf (Research Institute for Forest, Snow and Landscape). The program is called FARO (falling rocks) and was calibrated by using the data resulting from static pull tests of the single elements and 1:1 field trials.

With this simulation program it is not only possible to model punctual impacts but also distributed impact loads. The following figure illustrates an impact of a debris flow into a UX system. It is assumed that the debris flow only hits the middle section and that it hits the barrier first in the bottom part and then fills up the whole system.

\section{Measurement station of debris flow}

As it leaves from the development of these systems is indispensable the measurement in situ from the parameters that characterize to the flow as well as of the requesting in the barrier at the moment of the impact. Geobrugg in collaboration with WSL have been begun to develop stations of measurement in several places. Next showed in example, the instrumentation located in a station 
of measurement in the Illgraben river, Switzerland. The selection of the points where the measurement stations are located, is a very complex and important process, on the knowledge of the area at issue the efficiency in the process of obtaining of data will depend largely. In general, the measurement stations, are locate in places where a reduction of the cross-section area of the channel, through which, it happens with an adapted frequency, the mass of detritus, that is generated in all the area of deposition.

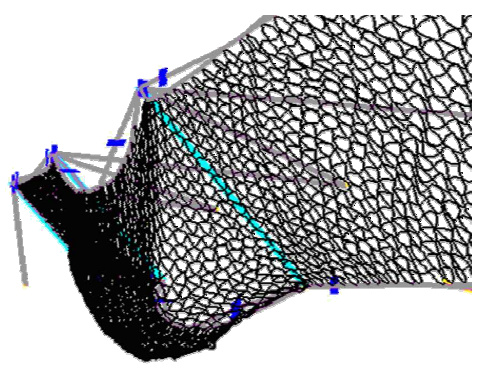

Figure 6: Impact of the debris flow into the UX barrier (modeled with FARO).

\subsection{Torrent instrumentation}

In order to activate the systems of measurement and recording, several geophons are used to initialize all the data logged, illumination and video systems. While the weather station, allows one to associate the debris flow phenomenon, with the predominant conditions of the weather.

With the target to determine of experimental form the average density of the detritus flow, a dynamic force plate has been constructed, that by means of a set of sensors allows to obtain, the instantaneous weight of the flow, in the measurement that this happening the phenomenon.

\subsection{Barrier instrumentation}

Simultaneously that is placed devices that allow to characterize the flow, is essential the positioning of sensors in the barrier so that the requesting in the landmarks of the system can be measured and thus to be able to calibrate the sizing process. In this case, a barrier Geobrugg $\mathrm{ROCCO}^{\circledR} \mathrm{VX}$ has been placed. The height of the barrier is of $3,5 \mathrm{~m}$ while the wide means of the cross section are of $12 \mathrm{~m}$ and ring net $\operatorname{ROCCO}^{\circledR}$ used in this location is $16 / 3 / 300$ (16 turns, $3 \mathrm{~mm}$ wire diameter, $300 \mathrm{~mm}$ ring diameter). The placed measuring instruments in the barrier are as follow: cells of load with capacity of $500 \mathrm{kN}$ each one, for the measurement of the forces in horizontal ropes; digital video camera; powerful illumination system; laser for the measurement of the fill height; data logged system. 
This barrier has been hit by three events during 2005. The barrier was filled since the first event, and successful supported the loads, generated in the rest of the events.

Table 2.

$\begin{array}{llll}\text { Date } & 07.18 .2005 & 08.02 .2005 & 08.18 .2005 \\ \text { Volume } & 19.000 \mathrm{~m}^{3} & 8.700 \mathrm{~m}^{3} & 5.600 \mathrm{~m}^{3} \\ \mathbf{Q}_{\max } & 24,1 \mathrm{~m}^{3} / \mathrm{s} & 17,9 \mathrm{~m}^{3} / \mathrm{s} & 7,5 \mathrm{~m}^{3} / \mathrm{s} \\ \mathbf{H}_{\max } & 1,30 \mathrm{~m} & 1,16 \mathrm{~m} & 0,80 \mathrm{~m}\end{array}$

With the results of these first measurements in 2.005 , have been able to corroborate several hypotheses, some of general character, that allow demonstrate the suitability of these flexible systems in front to the traditional ones. While, on the other hand it has been possible to verify, the form of work of the different devices integrates in the measurement system, its precise operation, in the hard conditions of work. With the occurrence of these events, also it has been possible to control the system mobile communications GSM, indispensable for the on line control of the operation. The knowledge of the weather conditions in the place before, during and after to the event, allows to make comparisons and establish, a certain extent, try to predict their occurrence. Although this is extremely difficult, since the generation of the torrent, does not follow standard rules.

\section{Conclusions}

The preliminary calculations and the phenomenon simulations in the computer, show that the debris flows, with volume until $1.000 \mathrm{~m}^{3}$ can be stopped using flexible barriers of steel ring nets. For such cases, it has been possible to corroborate that these flexible systems, are a true alternative to rigid systems, due to their great capacity of deformation, ideal to stop dynamic impacts. Due to the slight construction of the flexible barriers, they do not require of execution of way access, reason why they are easy to install and its cost in general is reasonable. Geobrugg VX/ UX Barriers can be used for two aims:

Debris flows stopped: halting of active detritus flows, retention of solid components within the flow to protect infrastructures, separation of the water and the solid material.

Debris flow control: substitution of concrete check dams, passive reduction of the erosive energy of the flow. Installed in series of several barriers in staggered form, it allows modification of the pending average, advantages by the cost of installation in zones difficult.

The location of the observation stations in high frequency places is essential for the calibration of the mathematical models of behavior of the barriers in front to the flow, as well as to know the characteristics the flow and use the results in similar areas. The requesting control, also allows the dimensioning of the 
anchorages system and the bearing capacity all the system in front to quasi-static loads. The steel rings net of the barriers are transparent and fit better in landscape than the massive steel or concrete structures.

\section{References}

[1] Ammann, Walter. Volkwein, Alex (2006). Debris flow test site Illgraben, Switzerland. Research result from test barrier 2005. WSL, Switzerland.

[2] Luis Fonseca, Roberto, et al. Madrid (2006). Sistemas flexibles de protección contra flujos de detritus.

[3] Roth Andrea, et al. Valencia (2005). Sistemas de protección contra flujos de detritus.

[4] Luis Fonseca, Roberto y Laguna Megal, Luis (2003). Dimensionamiento de la solución para la contención de flujos de detritus. Barranco de Casalón. Santa Cruz de Tenerife. Canarias.

[5] Roth Andrea, (2003). Design Concept VX / UX Protection System against Debris Flow.

[6] Duffy J.D., Peila A. (1999), Case studies on debris and mudslide barrier systems in California

[7] Mitzuyama et al. (1992), Prediction of debris flow peak discharge, Interpraevent, Bern, Bd. 4, 99-108

[8] Muraishi H., Sano S. (1997), Full scale rockfall test of ring net barrier and components

[9] PWRI (1988), Technical Standard for measures against debris flows (draft), Ministry of Construction, Japan.

[10] Rickenmann D. (1999), Empirical relationships for debris flows, Natural Hazards, 19(1), 47-77

[11] Rickenmann D. (2001), Estimation of debris flow impact on flexible wire rope barriers, Birmensdorf, interner Bericht, unver. ffentlicht

[12] Salzmann H. (2001), Debris Flow Mitigation by Means of Flexible Barriers, proceedings $14^{\text {th }}$ Southeast Asia Geotechnical Conference, Hong Kong

[13] Wartmann St., Salzmann H. (2002), Debris Flow and Floating Tree Impacts on Flexible Barriers

[14] Grassl, Hans; Volkwein, Axel; Bartelt; Perry and Wartmann, Stephan.MIT, USA (2003). Experimental and Numerical Modeling of Highly Flexible Rockfall Protection Barriers.

[15] Rorem, Erick. USA (2004). Performance of flexible Debris flows barriers in fire burned areas, San Bernardino. 